\title{
Inoculation with arbuscular micorrizhal fungi and organic compost from cocoa shell positively influence the growth and mineral nutrition of soursop plants (Annona muricata l.)
}

\author{
Gedeon Almeida Gomes Júnior ${ }^{1}$, Rafaela Alves Pereira ${ }^{2}$, \\ George Andrade Sodré ${ }^{3}$, Célio Kersul do Sacramneto ${ }^{4}$, Eduardo Gross ${ }^{5}$
}

\begin{abstract}
The aim of this study was to evaluate the effect of arbuscular mycorrhizal fungi inoculation (AMF - Acaulospora scrobiculata, Acaulospora colombiana and the mixture of these inocula) and doses of organic compost obtained from cocoa shell $\left(0,5,10,20\right.$ and $\left.30 \mathrm{~g} \mathrm{dm}^{-3}\right)$ on "Morada" soursop seedlings. The experimental design was a randomized block with 4 blocks in a $5 \mathrm{x} 4$ factorial scheme (AMF x organic compost). After 120 days of growth, it was observed that AMF inoculation increased height, stem diameter and shoot, root and total dry biomass. Organic compost stimulated mycorrhizal colonization and the number of spores with the addition up to 10 $\mathrm{g} \mathrm{dm}^{-3}$. Mycorrhizal inoculation promoted increases of $\mathrm{P}$ content in soursop leaves. Control plants did not show adequate response to doses of the organic compost applied and it was concluded that AMF inoculation combined with organic compost increased the growth and nutrition of soursop plants.
\end{abstract}

Index terms: Mycorrhiza, seedling production, residues, composting.

\section{Inoculação com fungos micorrízicos arbusculares e composto orgânico da casca de cacau influenciam positivamente o crescimento e a nutrição mineral da gravioleira (Annona muricata 1.)}

Corresponding author: egross@uesc.br

Received: March 06, 2018. Accepted: July 13, 2018.

Copyright: All the contents of this journal, except where otherwise noted, is licensed under a Creative Commons Attribution License.

\section{(cc) $\mathbf{E Y}$}

Resumo- O estudo objetivou avaliar o efeito da inoculação de fungos micorrízicos arbusculares (FMA - Acaulospora scrobiculata, Acaulospora colombiana, e a mistura desses inóculos) e de doses do composto orgânico da casca de cacau $\left(0 ; 5 ; 10 ; 20\right.$ e $\left.30 \mathrm{~g} \mathrm{dm}^{-3}\right)$ em mudas seminais de gravioleira tipo 'Morada'. O delineamento experimental foi o de blocos casualizados, com 4 blocos, e em esquema fatorial 5 x 4 (FMA x Composto orgânico). Após 120 dias de crescimento, observou-se que a inoculação com FMA promoveu maior altura, diâmetro do coleto, biomassa seca da parte aérea, da raiz e total. O composto orgânico estimulou a colonização micorrízica e o número de esporos com a adição de até $10 \mathrm{~g} \mathrm{dm}^{-3}$. A inoculação micorrízica promoveu incremento no teor de $\mathrm{P}$ na folha da gravioleira. As plantas-controle não apresentaram resposta adequada às doses do composto orgânico aplicadas, concluindo-se que a inoculação com o FMA, aliada à adubação orgânica, promoveu o crescimento e a nutrição de mudas de gravioleira.

Termos para indexação: Micorrizas, produção de mudas, resíduos, compostagem.

\footnotetext{
${ }^{1}$ Master in Plant Production, State University of Santa Cruz, Ilhéus-BA, BR. E-mail: geda_almeida@hotmail.com ${ }^{2} \mathrm{PhD}$ in Plant Production, State University of Santa Cruz, Ilhéus-BA, BR. E-mail: rafaelapereira2511 @ gmail.com; ${ }^{3} \mathrm{PhD}$ in Plant Production, Adjunct Professor, State University of Santa Cruz, Ilhéus-BA, BR. E-mail: gasodre@hotmail.com; ${ }^{4} \mathrm{PhD}$ in Plant Production, Adjunct Professor, State University of Santa Cruz, Ilhéus-BA, BR. E-mail: celiokersul@gmail.com; 5 PhD in Plant Biology, Adjunct Professor, State University of Santa Cruz, Ilhéus-BA, BR. E-mail: egross@uesc.br
} 


\section{Introduction}

Soursop (Annona muricata L.) is considered the second anonaceous in production and cultivated area in Brazil. Its cultivation has grown considerably in the last years, especially in southern Bahia due to the favorable edaphoclimatic conditions and as profitable alternative to cacao crop (LEMOS, 2014). The growing demand for fruits for fresh consumption, and especially for the agribusiness sector, has driven the expansion of the cultivated area, making the culture one of the main investment alternatives of the fruit sector of northeastern Brazil (COSTA et al., 2005; SAMARÃO et al., 2011).

According to Silva et al. (2011), the use of composted fertilizers may be an interesting alternative in the formation of soursop seedlings. Due to its large area planted with cacao, southern Bahia has great potential to generate residues, and the cacao fruit shell is the main organic residue accumulated in crops, which when not properly reused, may be a source of inoculum for pathogenic fungi of cocoa culture (MORORÓ, 2012).

Several destinations can be given to cacao fruit shell: extraction of pectins (BERBERT, 1972), animal feed (ABIOLA, 1991) and gums (FIGUEIRA et al., 1993) and finally composting, being a very viable practice for producers, serving as organic fertilizer due to the high potassium levels present in shell (SODRÉ et al., 2012). Composting stands out among biological waste treatment processes by reducing their pollutant potential and converting them into organic compost capable of recycling nutrients in the soil (DOMÍNGUEZ; GÓMEZBRANDÓN, 2010).

Arbuscular mycorrhizal fungi (AMF) are soil microorganisms that establish a mutualistic association with most vascular plants, where the plant provides energy substrate through photoassimilates to the fungus, which in turn, using its external mycelium, captures soil nutrients and transfers them to the host plant, providing greater plant growth (GENRE; BONFANTE 2010).

Inoculation with arbuscular mycorrhizal fungi (AMF) has been studied in some fruits (FARIAS et al., 2014: RITER NETO et al., 2014; SOARES et al., 2012; NUNES et al., 2013; COELHO et al., 2012; ANZANELLO et al., 2011), including soursop (SAMARÃO et al., 2011). AMF can be used in a profitable way for agriculture, considering that symbiosis increases the area of nutrient absorption by the plant due to the presence of fungal root hyphae, which capture nutrients, having greater action on those of reduced mobility in soil such as $\mathrm{P}$ and $\mathrm{Zn}$ (SMITH \& READ, 2008). In addition, mycorrhizal fungi play a key role in the mineralization process of organic matter (PATERSON et al., 2016), increasing soil fertility (JOHNSON et al., 2016), and may also be stimulated by the addition of organic matter to the soil (SHELDRAKE et al., 2017).
The positive effect of the combined application of AMF and organic wastes is documented in literature. Passionflower (Passiflora allata Curtis) seedlings inoculated with Gigaspora albida and cultivated in soil with the addition of vermicompost showed increased growth and production (OLIVEIRA et al., 2015). Santana et al. (2015) reported that the addition of vermicompost allied to the inoculation of Rhizophagus clarus increased $\mathrm{Cu}$ extraction by Canavalia ensiformis plants in contaminated soils. Nascimento et al. (2014) reported that increasing doses of agroindustrial sugarcane residues did not affect the mycorrhizal colonization rate in Manihot esculenta plants and AMF sporulation.

Fertilization with organic amandment and arbuscular mycorrhizal fungi inoculation increase plant growth. However, few studies have evaluated the interaction of cocoa fruit shell and arbuscular fungi inoculation on the growth of soursop seedlings. The hypothesis of this study is that the addition of organic compost in mycorrhizal plants increases plant growth. Thus, the aim of this work was to evaluate the effect of organic cocoa shell compost and AMF inoculation on the growth of 'Morada' soursop seedlings.

\section{Material and Methods}

The experiment was conducted in greenhouse at the State University of Santa Cruz, Ilheus, Brazil (1447'47.4”S 39¹0'25.3”W), between May and September of 2014. Soursop (Annona muricata L.) seeds originated from fruits of the same matrix plant were sown in pots containing $5 \mathrm{dm}^{3}$ of soil. This soil was collected from the A horizon $(0-20 \mathrm{~cm})$ of a Typical Yellow Dystrophic Argisol (Araújo et al., 2001). The soil showed the following chemical properties: $5.1\left(\mathrm{pH}\right.$ in $\left.\mathrm{H}_{2} \mathrm{O}\right) ; 4.0 \mathrm{mg}$ $\mathrm{dm}^{-3}(\mathrm{P}) ; 16 \mathrm{mg} \mathrm{dm}^{-3}(\mathrm{~K}) ; 1.0 \mathrm{cmol}_{\mathrm{c}} \mathrm{dm}^{-3}(\mathrm{Ca}) ; 0.2 \mathrm{cmol}_{\mathrm{c}}$ $\mathrm{dm}^{-3}(\mathrm{Mg}) ; 0.4 \mathrm{cmol}_{\mathrm{c}} \mathrm{dm}^{-3}$ (Al); $21 \mathrm{~g} \mathrm{~kg}^{-3}$ (MO); $71 \mathrm{mg}$ $\mathrm{dm}^{-3}(\mathrm{Fe}) ; 1.0 \mathrm{mg} \mathrm{dm}^{-3}(\mathrm{Zn}) ; 1.0 \mathrm{mg} \mathrm{dm}^{-3}(\mathrm{Cu}) ; 11.0 \mathrm{mg}$ $\mathrm{dm}^{-3}(\mathrm{Mn}) ; 1.0 \mathrm{mg} \mathrm{dm}^{-3}(\mathrm{~B}) ; 19 \mathrm{mg} \mathrm{dm}^{-3}(\mathrm{Na}) ; 1.0 \mathrm{cmol}_{\mathrm{c}}$ $\mathrm{dm}^{-3}$ (SB); $4.3 \mathrm{cmol}_{\mathrm{c}} \mathrm{dm}^{-3}$ (CTC at pH 7); $22 \%(\mathrm{~V}) ; 3.4$ $\mathrm{cmol}_{\mathrm{c}} \mathrm{dm}^{-3}$ (Potential Acidity). The $\mathrm{pH}$ was corrected to $\mathrm{pH} 6.0$ with dolomitic limestone (PRNT 95\%) using the incubation curve method (SOUSA et al., 2007) in an experiment carried out prior to the installation of the experiment.

Organic compost was produced using cocoa fruit shell crushed and enriched with natural phosphate (source of P). The composting stacks were arranged in conical geometric configuration and the composting process was revolving or "Window". Stacks were revolved every 15 days in the first 90 days and temperature was biweekly monitored. After 120 days, composting was dried at room temperature, sieved in a $4 \mathrm{~mm}$ mesh and chemically analyzed. The organic compost had the following chemical 
properties: $7.41\left(\mathrm{pH}\right.$ in $\left.\mathrm{CaCl}_{2}\right) ; 52,1 \mathrm{~g} \mathrm{~kg}^{-1}(\mathrm{P}), 24.1 \mathrm{~g} \mathrm{~kg}^{-1}$ (K), $72.4 \mathrm{~g} \mathrm{~kg}^{-1}(\mathrm{Ca}), 6.4 \mathrm{~g} \mathrm{~kg}^{-1}(\mathrm{Mg}) ; 2.7 \mathrm{~g} \mathrm{~kg}^{-1} \mathrm{~S}\left(\mathrm{~g} \mathrm{~kg}^{-1}\right)$; $57 \mathrm{mg} \mathrm{kg}^{-1}(\mathrm{Cu}) ; 185 \mathrm{mg} \mathrm{kg}^{-1}(\mathrm{Mn}) ; 195 \mathrm{mg} \mathrm{kg}^{-1}(\mathrm{Zn}) ; 7656$ $\mathrm{mg} \mathrm{kg}^{-1}(\mathrm{Fe}) ; 16 \mathrm{mg} \mathrm{kg}^{-1}(\mathrm{~B})$. Organic compost doses were calculated based on $\mathrm{P}$ content and the central dose based on the response to fertilization of this nutrient to soursop (BARBOSA et al., 2003).

Arbuscular mycorrhizal fungi inocula were obtained from Embrapa Agrobiologia, located in the municipality of Seropédica (RJ) and were added at approximately $3 \mathrm{~cm}$ in depth at density of 30 spores per pot. The statistical design was a randomized complete block design, consisting of 4 blocks, in a 4 x 5 factorial scheme, with 4 mycorrhizal treatments: control not inoculated, inoculation with Acaulospora scrobiculata, with Acaulospora colombiana and the mixture of these inocula (MIX); and 5 organic compost doses based on cocoa shell $(0,5,10,20$ and 30 $\mathrm{g} \mathrm{dm}^{-3}$ ), totaling 20 treatments with 1 replicate per block.

The selected soursop seeds were disinfested with $1 \%$ sodium hypochlorite solution for two minutes, washed in distilled water and placed to dry in the shade for 24 hours. They were then seeded in $150 \mathrm{~cm}^{3}$ tubes containing sterilized expanded vermiculite. At the end of 30 days, seedlings were transplanted to containers with capacity of $5 \mathrm{dm}^{3}$, containing autoclaved soil with the respective organic compost dose already incorporated. At the time of transplanting, AMF inoculation was carried out near the root system of plants.

The following variables were evaluated at 120 days after inoculation of soursop seedlings: plant height, stem diameter, dry biomass of plants, phosphorus content, AMF spore density and mycorrhizal colonization percentage. Plant height and stem diameter values were measured using tape measure and digital caliper, respectively. Plants were then placed in greenhouse at $65^{\circ} \mathrm{C}$ for 72 hours and then weighed in analytical scale with accuracy of 0.01 g. Total dry biomass was obtained by summing the dry biomass values of shoot and root. After drying, diagnostic leaf samples were processed in Willey mill and stored in hermetically sealed vials. The material was submitted to oxidation by nitroperchloric digestion and the $\mathrm{P}$ contents were determined by the molybdate method in molecular absorption spectrophotometer (SILVA, 2009). P contents were used to determine the $\mathrm{P}$ content in the shoot dry biomass.

In order to estimate the percentage of mycorrhizal colonization in plant root samples, the technique of bleaching in $10 \% \mathrm{KOH}$ and staining with trypan blue was used, according to methodology described by Phillips and Hayman (1970). Colonization quantification was performed by the intersection method of Mcgonigle et al. (1990) and roots that had vesicles, spores, hyphae and arbuscles were considered colonized. The number of mycorrhizal fungi spores in $50 \mathrm{~g}$ of moist soil was obtained by the wet sieving method of Gerdemann and Nicolson
(1963). Samples were quantified using stereomicroscope in 40X magnification with the aid of canaletted plate.

For statistical analyses, Komolgorov-Smirnov test was performed to evaluate the normality of data distribution. Analysis of variance was then applied and Tukey's test ( $p<0.05)$ was used to compare qualitative treatments (AMF inoculation). For quantitative treatments, regression was performed, being chosen the model representative of the biological response and having a significant effect by the $t$ test $(p<0.05)$ for the equation parameters. Analyses were performed using the R (CORE TEAM, 2017) and Statistica software (STATSOFT, 2013).

\section{Results and discussion}

There was a significant interaction between applied mycorrhizal treatments and organic compost doses incorporated into the soil $(p<0.05)$ for variables plant height, stem diameter, root dry biomass and total dry biomass. The factors influenced in isolation the shoot dry biomass variable (Table 1). The combined application of organic compost and AMF may result in a positive synergistic effect on plant growth (SILVA et al., 2008). The highest increases in host plant growth are generally observed under conditions of low soil fertility (SILVA et al., 2008; CHU et al., 2001) and this occurred with soursop seedlings inoculated with Acaulospora colombiana, Acaulospora scrobiculata, and the mixture of two inocula without the addition of the organic compost, as will be discussed later. Coelho et al. (2012) concluded that Annona squamosa L. seedlings inoculated with Gigaspora albida showed better performance in the absence of phosphate fertilization.

Inoculation with Acaulospora colombiana positively influenced plant height $(\mathrm{H})$ with increments greater than $50 \%$ when compared to control plants. However, plants fertilized with $30 \mathrm{~g} \mathrm{dm}^{-3}$ did not differ from control plants. At the same dose, plants inoculated with Acaulospora colombiana and Mix differed from control plants, with Mix plants statistically superior to the other treatments (Table 2). The use of mixed inoculum composed of species with different strategies may present better results for host plants and may therefore be more adequate than the introduction of a single fungus species (LIMA et al., 2015).

Fungi Acaulospora colombiana and Acaulospora scrobiculata promoted increase around $33 \%$ and $13 \%$, respectively, in plant height when compared to treatment without inoculation. For stem diameter (SD), the increments observed in plants inoculated with A. colombiana also had statistically higher values than those inoculated with $A$. scrobiculata (30\% and $13 \%$, respectively). Plants respond differently to mycorrhization, and different mycorrhizal fungi species induce diverse effects not only on the colonization level but also on plant growth (BURLEIGH, 
et al., 2002). Samarão et al. (2011) observed increases in height and diameter similar in soursop plants inoculated with Gigaspora margarita and Glomus clarum.

The effect of mycorrhizal inoculation on root dry biomass (RDB), shoot dry biomass (SDB) and total dry biomass (TDB) of soursop was evaluated within each organic compost dose (Table 3). For variable RDB, inoculation with $A$. colombiana, $A$. scrobiculata and the mixture of spores of these two species (Mix) positively influenced this attribute. It is worth mentioning the effect of AMF on biomass gain of the root system in plants not fertilized with cocoa shell, in which, on average, there were $264 \%$ increases for plants inoculated with A. colombiana, $180 \%$ for those inoculated with $A$. scrobiculata and $160 \%$ for those inoculated with Mix in relation to uninoculated plants.

Consistent increases in relation to control (plants not inoculated with AMF) also occurred for variable SDB in plants inoculated with $A$. colombiana (419\%), $A$. scrobiculata (367\%) and Mix (450\%). Plants inoculated with $A$. colombiana and A. scrobiculata presented a different response pattern for variable TDB, with higher biomass accumulation at doses 0,5 and $10 \mathrm{~g} \mathrm{dm}^{-3}$ of organic compost for plants inoculated with $A$. colombiana, while for plants inoculated with $A$. scrobiculata, the greatest biomass accumulation of soursop seedlings occurred at doses of 20 and $30 \mathrm{~g} \mathrm{dm}^{-3}$ of the compost applied to the soil, and it could be concluded that $A$. scrobiculata is better adapted to substrates richer in nutrients. The biomass increase is probably a consequence of the improvement of the nutritional status of the mycorrhizal plant, in which extracellular hyphae expand the contact surface of the plant with the soil, colonizing sites previously not reached by the root and thus optimizing nutrient absorption (MOREIRA; SIQUEIRA, 2006).

Mycorrhizal colonization and number of spores were significantly influenced by the interaction $(p<0.05)$ between AMF inoculation and organic compost doses (Table 4). Mycorrhizal colonization data showed quadratic behavior, with reductions in the colonization percentage of soursop roots at higher organic compost doses (Figure 2 ). However, the mycorrhizal colonization rate of seedlings did not decrease consistently, with micorrization values above $50 \%$ being observed at the highest organic compost dose $\left(30 \mathrm{~g} \mathrm{dm}^{-3}\right)$. Similar effect was reported by Coelho et al. (2012), who concluded that vermicompost application increased the mycorrhizal colonization rate of Annona squamosa seedlings inoculated with Gigaspora albida; and that the application of soluble P significantly decreases root colonization. Silva et al. (2008) concluded that the application of vermicompost positively influenced colonization in the symbiosis between Gigaspora albida and soursop. Balota et al. (2011) concluded that the addition of $\mathrm{P}$ doses negatively influenced mycorrhizal colonization in soursop seedlings.
The addition of cocoa shell compost also influenced AMF sporulation. A. colombiana and A. scrobiculata presented response similar to the addition of organic compost to the soil, with an increase in the number of spores up to the dose of $10 \mathrm{~g} \mathrm{dm}^{-3}$. Reductions in the number of spores were observed in the other doses. This can be explained by the presence of $\mathrm{P}$ in the organic compost doses applied. Similar result was obtained by Silva et al. (2008), who concluded that soil fertilized with vermicompost showed inhibition of Acaulospora longula sporulation. As suggested by Moreira and Siqueira (2006), high $\mathrm{P}$ levels in the soil negatively influence the action of AMF. In soursop, sporulation was negatively influenced by the addition of P doses (BALOTA et al., 2011). Similarly, in Annona squamosa L. seedlings, phosphate fertilization mitigated the benefits of mycorrhization (COELHO et al., 2012).

Regarding P levels in soursop leaves, the organic compost exerted a quadratic effect on plants inoculated with A. colombiana, A. scrobiculata and Mix and positively influenced the absorption of this macronutrient. For plants without inoculation (control), the adjustment was linear (Figure 3). Due to the quadratic behavior, it was possible to verify that organic compost doses lower than 30 $\mathrm{g} \mathrm{dm}^{-3}$ of soil provided higher values. For plants inoculated with $A$. scrobiculata, the ideal organic compost dose was $10 \mathrm{~g} \mathrm{dm}^{-3}$ (520 $\mathrm{mg} \mathrm{P} \mathrm{dm}^{-3}$ ) soil. In plants inoculated with A. colombiana, the ideal organic compost dose was 15.6 $\mathrm{g} \mathrm{dm}^{-3}\left(810 \mathrm{mg} \mathrm{P} \mathrm{dm}^{-3}\right)$ soil. An ideal organic compost dose of $10.6 \mathrm{~g} \mathrm{dm}^{-3}$ (550 $\mathrm{mg} \mathrm{P} \mathrm{dm}^{-3}$ ) soil was observed for Mix plants. It was observed that different arbuscular mycorrhizal fungi species induce diverse effects also in $\mathrm{P}$ absorption. In some cases, the molecular and physiological response of the plant to the fungus can be explained by the ability of the fungus to supply the host plant with inorganic phosphate (BURLEIGH \& BECHMANN, 2002).

Inoculation with Gigaspora magarita and Glomus clarum resulted in soursop seedlings at 90 DAP greater $\mathrm{P}$ absorption (SAMARÃO et al., 2011). These authors also highlight the importance of AMF inoculation in a system of soursop seedling production, since uninoculated plants did not respond to phosphate fertilization. These results corroborate results found in soursop seedlings inoculated with A. colombiana, A. scrobiculata and Mix, that potentiated the P uptake by plants. This result is related to the performance of extraradicular hyphae, which promote greater exploration of the root area and increase nutrient absorption with low mobility in the soil (EL SHAIK \& MOHAMMED, 2009).

Mycorrhizal colonization, among other factors, can be affected by high $\mathrm{P}$ levels in the soil, which reduces the benefits of AMF in promoting adequate plant nutrition (BOLAN et al., 1984). This effect was observed in the present study, where the $\mathrm{P}$ content in soursop leaves showed decreases at higher organic compost doses, 
which can be attributed to the fact that in substrates richer in nutrients, the activity of AMF is generally reduced (Figure 3). Dalanhol et al. (2016) did not observe the effect of AMF inoculation on Eugenia uniflora seedlings, attributing it to the high P levels in the substrate. High $\mathrm{P}$ uptake favors the synthesis of phospholipids and reduces the permeability of cell membranes and ends up by hindering the penetration of hyphae into the roots. Moreover, it is believed that high $\mathrm{P}$ concentration in the substrate increases the photosynthetic rate of the plant, increasing the amount of sucrose in the plant, which can cause low root colonization by AMF (RAMOS \& MARTINS, 2010).

Inoculation with $A$. scrobiculata, A. colombiana and Mix provided an increase in the $\mathrm{P}$ content of the shoot dry biomass when compared to control plants. The increments for this attribute in plants without fertilization were those that presented greater prominence, highlighting that inoculation with $A$. scrobiculata, A. colombiana and Mix increased on average $3695 \%, 3426 \%$ and $3267 \%$, respectively. It was also reported that the increase rate reduced as the level of organic fertilization increased (Table 6). Similar results were reported with Gigaspora magarita and Glomus clarum inoculation by Samarão et al. (2011) and Farias et al. (2014) in soursop and blueberry seedlings, respectively. Silva et al. (2017) reported that inoculation with Acaulospora colombiana provided an increase in the P content in the order of $2,400 \%$ in relation to control in Australian cedar seedlings. Due to its reduced mobility, the transport of $\mathrm{P}$ in the soil solution hinders the absorption of this nutrient by the plant and AMF inoculation becomes an alternative, since these microorganisms increase the root exploration area (CARDOSO et al. 2010).

In this study, responses to organic compost doses and $\mathrm{AMF}$ inoculation made evident the effects of these factors on the development of soursop seedlings. The results indicate the possibility of using the cocoa shell compost as well as AMF inoculation in the process of formation of soursop seedlings.

Table 1. Summary of variance analysis for plant height (H), stem diameter (SD), root dry biomass (RDB), dry shoot biomass (DSB) and total dry biomass (TDB) of soursop seedlings at 120 days after planting inoculated with AMF and fertilized with organic compost.

\begin{tabular}{ccccccc}
\hline \multirow{2}{*}{ SV } & \multirow{2}{*}{ DF } & \multicolumn{5}{c}{ Mean square } \\
\cline { 3 - 7 } & & $\mathrm{H}$ & $\mathrm{SD}$ & $\mathrm{RDB}$ & $\mathrm{DSB}$ & $\mathrm{TDB}$ \\
\hline Block & 3 & 96.43 & 0.1591 & 0.0819 & $3.665^{*}$ & 3.734 \\
AMF & 3 & $577.18^{*}$ & $6.3512^{*}$ & $6.2368^{*}$ & $81.774^{*}$ & $131.960^{*}$ \\
Compost & 4 & 42.99 & $3.6059^{*}$ & $1.1654^{*}$ & $4.289^{*}$ & $8.646^{*}$ \\
AMF*Compost & 12 & $122.52^{*}$ & $0.9290^{*}$ & $0.5377^{*}$ & 1.399 & $3.266^{*}$ \\
Residue & 57 & 57.73 & 0.2307 & 0.1363 & 0.833 & 1.052 \\
\hline VC $(\%)$ & & 26.31 & 8.88 & 18.98 & 19.7 & 15.6 \\
\hline
\end{tabular}

* F Test $(\mathrm{p}<0.05)$; SV: Source of variation; DF: Degree of freedom; VC: Variation coefficient

Table 2. Mean plant height $(\mathrm{H})$ and stem diameter (SD) soursop seedlings at 120 days after planting inoculated with AMF and fertilized with organic ccompost.

\begin{tabular}{cccccc}
\hline & Height $(\mathrm{cm})$ & \multicolumn{5}{c}{ Organic compost $\left(\mathrm{g} \mathrm{dm}^{-3}\right)$} \\
\cline { 2 - 6 } Mycorrhizal treatment & 0 & 5 & 10 & 20 & 30 \\
\hline Control & $15.5 \mathrm{~b}$ & $15.9 \mathrm{~b}$ & $16.3 \mathrm{c}$ & $16.8 \mathrm{~b}$ & $18.5 \mathrm{c}$ \\
Acaulospora scrobiculata & $17.5 \mathrm{ab}$ & $19.7 \mathrm{ab}$ & $19.7 \mathrm{bc}$ & $27.3 \mathrm{a}$ & $24.2 \mathrm{~b}$ \\
Acaulospora colombiana & $20.6 \mathrm{a}$ & $21.0 \mathrm{a}$ & $23.4 \mathrm{ab}$ & $26.0 \mathrm{a}$ & $18.7 \mathrm{c}$ \\
Mix & $18.2 \mathrm{ab}$ & $19.9 \mathrm{ab}$ & $26.8 \mathrm{a}$ & $27.3 \mathrm{a}$ & $29.1 \mathrm{a}$ \\
\hline & \multicolumn{5}{c}{} \\
\hline & Stem diameter $(\mathrm{mm})$ & Organic compost $\left(\mathrm{g} \mathrm{dm}^{-3}\right)$ \\
\hline Mycorrhizal treatment & 0 & 5 & 10 & 20 \\
\hline Control & $4.1 \mathrm{c}$ & $4.4 \mathrm{~b}$ & $4.5 \mathrm{c}$ & $4.6 \mathrm{~b}$ & $5.0 \mathrm{c}$ \\
Acaulospora scrobiculata & $4.7 \mathrm{bc}$ & $5.0 \mathrm{ab}$ & $5.2 \mathrm{bc}$ & $6.3 \mathrm{a}$ & $6.1 \mathrm{ab}$ \\
Acaulospora colombiana & $5.0 \mathrm{ab}$ & $5.7 \mathrm{a}$ & $5.9 \mathrm{~b}$ & $6.1 \mathrm{a}$ & $5.6 \mathrm{bc}$ \\
Mix & $5.6 \mathrm{a}$ & $5.4 \mathrm{a}$ & $6.8 \mathrm{a}$ & $6.6 \mathrm{a}$ & $6.6 \mathrm{a}$ \\
\hline
\end{tabular}

\footnotetext{
* Means followed by the same letters in columns do not differ statistically by the Tukey test $(\mathrm{p} \leq 0.05)$.
} 
Table 3. Mean values of root dry biomass (RDB), dry shoot biomass (DSB) and total dry biomass (TDB) at 120 days after planting of soursop seedlings inoculated with AMF and fertilized with organic compost.

\begin{tabular}{|c|c|c|c|c|c|}
\hline \multicolumn{6}{|c|}{ Root dry biomass $(\mathrm{g})$} \\
\hline \multirow[b]{2}{*}{ Mycorrhizal treatment } & \multicolumn{5}{|c|}{ Organic compost $\left(\mathrm{g} \mathrm{dm}^{-3}\right)$} \\
\hline & 0 & 5 & 10 & 20 & 30 \\
\hline Control & $0.67 \mathrm{~b}$ & $0.67 \mathrm{~b}$ & $0.84 \mathrm{~b}$ & $0.79 \mathrm{~b}$ & $2.00 \mathrm{ab}$ \\
\hline Acaulospora scrobiculata & $1.88 \mathrm{a}$ & $1.87 \mathrm{a}$ & $1.85 \mathrm{a}$ & $2.98 \mathrm{a}$ & $2.77 \mathrm{a}$ \\
\hline Acaulospora colombiana & $2.44 \mathrm{a}$ & $2.32 \mathrm{a}$ & $2.65 \mathrm{a}$ & $2.33 \mathrm{a}$ & $1.93 \mathrm{~b}$ \\
\hline Mix & $1.74 \mathrm{a}$ & $1.61 \mathrm{a}$ & $2.21 \mathrm{a}$ & $2.72 \mathrm{a}$ & $2.59 \mathrm{ab}$ \\
\hline \multicolumn{6}{|c|}{ Shoot dry biomass ${ }^{1}(\mathrm{~g})$} \\
\hline Control & & & $1.13 \mathrm{c}$ & & \\
\hline Acaulospora scrobiculata & & & $5.28 \mathrm{~b}$ & & \\
\hline Acaulospora colombiana & & & $5.87 \mathrm{ab}$ & & \\
\hline Mix & & & $6.24 \mathrm{a}$ & & \\
\hline \multicolumn{6}{|c|}{ Total dry biomass $(\mathrm{g})$} \\
\hline Control & $1.35 \mathrm{c}$ & $1.34 \mathrm{~b}$ & $1.77 \mathrm{c}$ & $2.22 \mathrm{~b}$ & $3.93 \mathrm{~b}$ \\
\hline Acaulospora scrobiculata & $6.30 \mathrm{a}$ & $6.45 \mathrm{a}$ & $7.15 \mathrm{~b}$ & $9.15 \mathrm{a}$ & $8.70 \mathrm{a}$ \\
\hline Acaulospora colombiana & $8.09 \mathrm{a}$ & $7.92 \mathrm{a}$ & $9.81 \mathrm{a}$ & $8.26 \mathrm{a}$ & $6.99 \mathrm{a}$ \\
\hline Mix & $6.42 \mathrm{a}$ & $7.36 \mathrm{a}$ & $9.88 \mathrm{a}$ & $9.20 \mathrm{a}$ & $9.22 \mathrm{a}$ \\
\hline
\end{tabular}

* Means followed by the same letters in columns do not differ statistically by the Tukey test ( $\leq \leq 0.05)$.

${ }^{1}$ There was no interaction AMF * Organic compost.

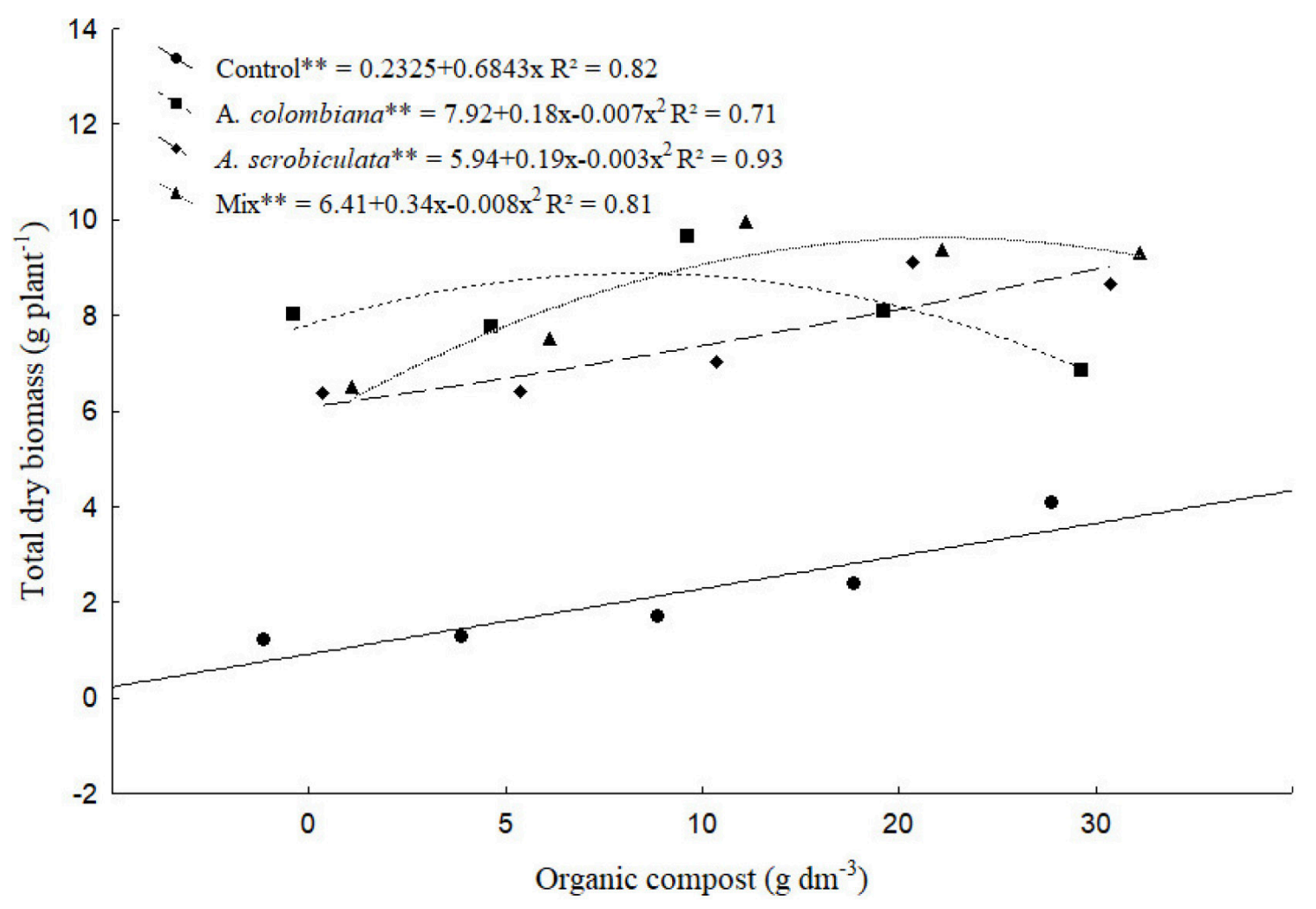

Figure 1. Regression analysis graph for mean dry biomass total of soursop seedlings at 120 days after planting submitted to different doses of organic compost and inoculated with Acaulospora colombiana, Acaulospora scrobiculata and the mixture of these two mycorrhizal fungi (MIX) and not inoculated (control). 
Table 4. Summary of variance analysis for mycorrhizal colonization and number of spores.

\begin{tabular}{lccc}
\hline \multirow{2}{*}{ SV } & DF & \multicolumn{2}{c}{ Mean square } \\
\cline { 3 - 4 } & & Mycorrhizal colonization & Number of spores \\
\hline Block & 3 & $118.4^{*}$ & 293 \\
AMF & 3 & $23677.7^{*}$ & $845968^{*}$ \\
Compost & 4 & $1874.8^{*}$ & $227956^{*}$ \\
AMF*Compost & 12 & $251.5^{*}$ & $29712^{*}$ \\
Residue & 57 & 281.7 & 1109 \\
\hline VC $(\%)$ & & 11.13 & 10.53 \\
\hline
\end{tabular}

* F Test $(\mathrm{p}<0.05)$; SV: Source of variation; DF: Degree of freedom; VC: Variation coefficient

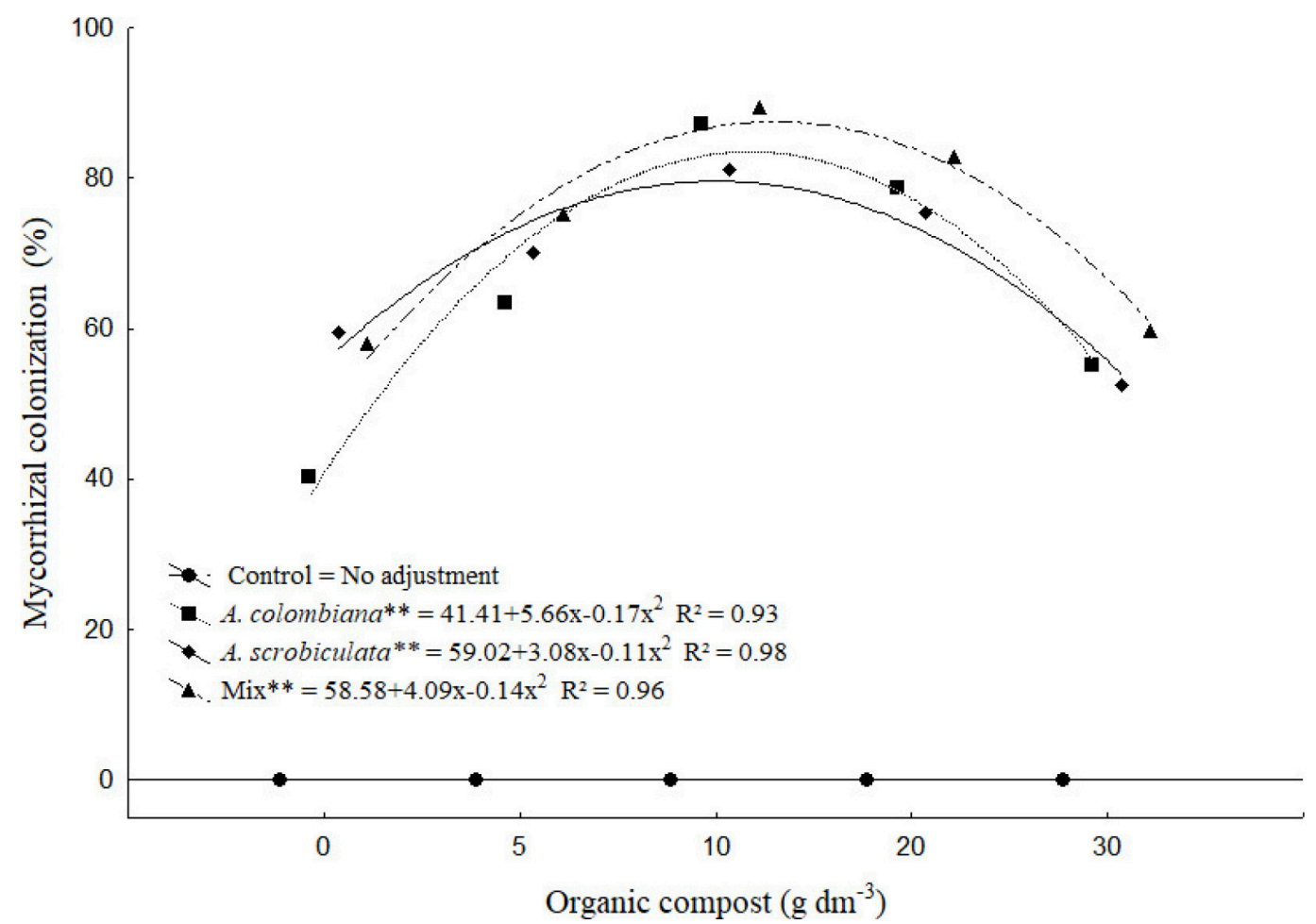

Figure 2. Regression analysis graph for the degree of mycorrhizal colonization of soursop submitted to different doses of organic compost and inoculated with Acaulospora colombiana, Acaulospora scrobiculata and the mixture of these two mycorrhizal fungi (MIX) and not uninoculated plants (control).

Table 5. Mean values and adjustment of regression models of AMF spore density.

\begin{tabular}{cccccc}
\hline & \multicolumn{5}{c}{ Organic compost $\left(\mathrm{g} \mathrm{dm}^{-3}\right)$} \\
\cline { 2 - 5 } Mycorrhizal treatment & 0 & 5 & 10 & 20 & 30 \\
\hline Control & $17.0 \mathrm{~d}$ & $14.5 \mathrm{c}$ & $16.2 \mathrm{c}$ & $17.5 \mathrm{c}$ & $16.50 \mathrm{~b}$ \\
Acaulospora scrobiculata & $219.7 \mathrm{~b}$ & $360.7 \mathrm{a}$ & $585.7 \mathrm{~b}$ & $495.5 \mathrm{~b}$ & $361.2 \mathrm{a}$ \\
Acaulospora colombiana & $112.0 \mathrm{c}$ & $254.0 \mathrm{~b}$ & $576.7 \mathrm{~b}$ & $492.2 \mathrm{~b}$ & $392.2 \mathrm{a}$ \\
Mix & $302.2 \mathrm{a}$ & $410.7 \mathrm{a}$ & $689.5 \mathrm{a}$ & $594.5 \mathrm{a}$ & $399.2 \mathrm{a}$ \\
\hline & Regression & Equation & $\mathrm{R}^{2}$ \\
\hline Control & \multicolumn{5}{c}{ Not significant } \\
Acaulospora scrobiculata & $\mathrm{Y}^{* *}=222.8488+40.9061 \mathrm{X}-1.3684 \mathrm{X}^{2}$ & 0.87 \\
Acaulospora colombiana & $\mathrm{Y}^{* *}=105.8067+49.9806 \mathrm{X}-1.3684 \mathrm{X}^{2}$ & 0.85 \\
Mix & $\mathrm{Y}^{* *}=287.2790+45.7348 \mathrm{X}-1.4125 \mathrm{X}^{2}$ & 0.86 \\
\hline
\end{tabular}

* Means followed by the same letters in columns do not differ statistically by the Tukey test $(\mathrm{p} \leq 0.05)$.

** Significant at $1 \%$ probability. 


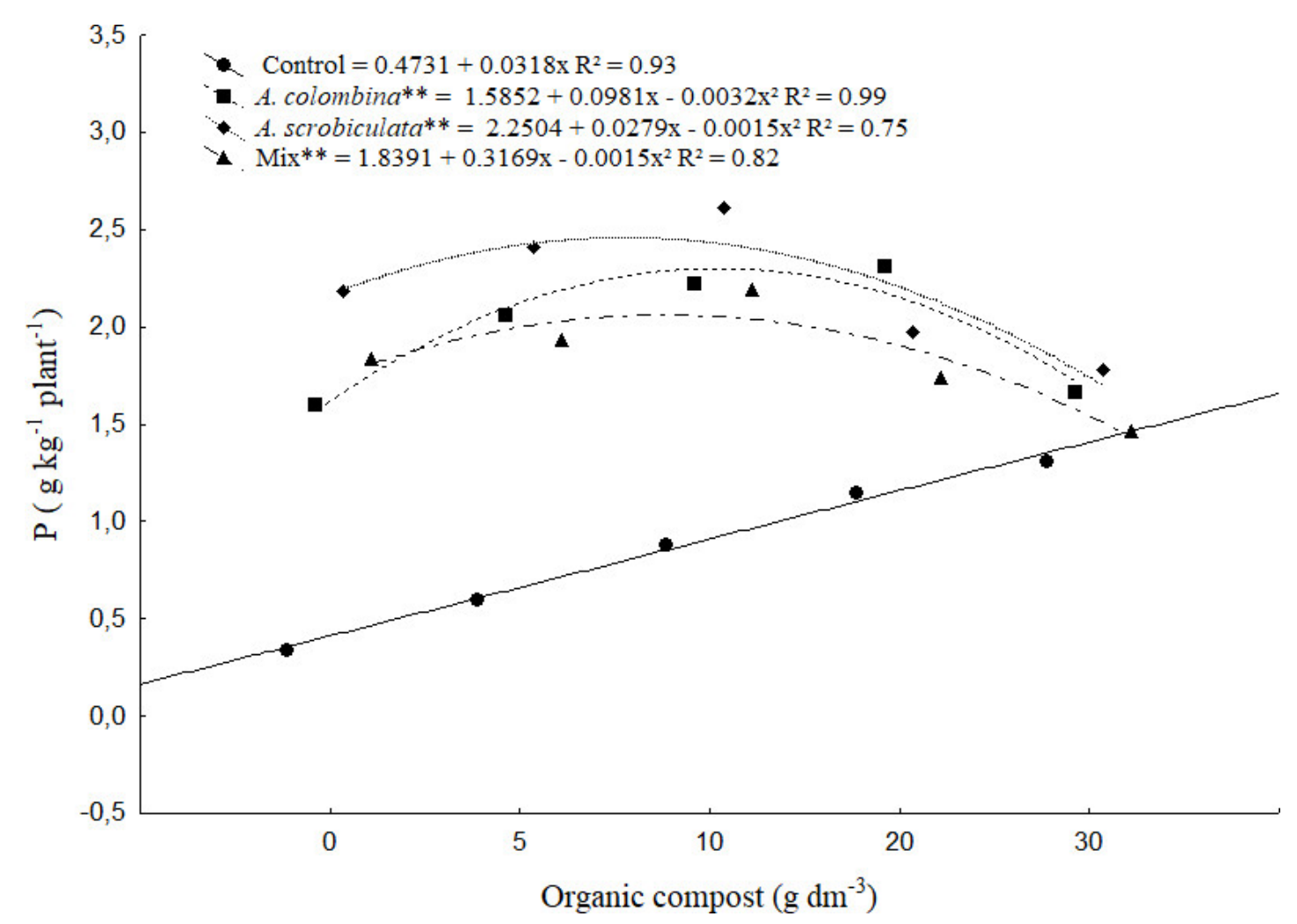

Figure 3. Regression analysis for the P content in leaves of soursop inoculated with Acaulospora scrobiculata, Acaulospora colombiana and the mixture of these two fungi and of uninoculated (control) plants submitted to different doses of organic compost.

Table 6. Mean values of $\mathrm{P}\left(\mathrm{mg} \mathrm{plant}^{-1}\right)$ content of dry shoot biomass of soursop seedlings inoculated with AMF and fertilized with organic compost.

\begin{tabular}{cccccc}
\hline & \multicolumn{5}{c}{ Organic compost $\left(\mathrm{g} \mathrm{dm}^{-3}\right)$} \\
\cline { 2 - 6 } Mycorrhizal treatment & 0 & 5 & 10 & 20 & 30 \\
\hline Control & $0.25 \mathrm{~b}$ & $0.42 \mathrm{c}$ & $0.85 \mathrm{c}$ & $1.69 \mathrm{c}$ & $2.59 \mathrm{c}$ \\
Acaulospora scrobiculata & $9.55 \mathrm{a}$ & $10.90 \mathrm{a}$ & $13.67 \mathrm{~b}$ & $12.03 \mathrm{a}$ & $10.38 \mathrm{a}$ \\
Acaulospora colombiana & $8.87 \mathrm{a}$ & $11.42 \mathrm{a}$ & $15.75 \mathrm{a}$ & $13.52 \mathrm{a}$ & $8.30 \mathrm{~b}$ \\
Mix & $8.47 \mathrm{a}$ & $10.98 \mathrm{a}$ & $16.64 \mathrm{a}$ & $11.08 \mathrm{~b}$ & $9.48 \mathrm{ab}$ \\
\hline
\end{tabular}

*Means followed by the same letters in columns do not differ statistically by the Tukey test ( $\mathrm{p} \leq 0.05)$.

\section{Conclusions}

Inoculation of mycorrhizal fungi and the addition of organic compost to the soil were synergistic for the initial development of soursop seedlings.

AMF inoculation stimulated $\mathrm{P}$ uptake, with reduction in foliar $\mathrm{P}$ contents at higher organic compost doses applied.

The organic cocoa shell compost positively influenced the degree of mycorrhizal colonization and AMF sporulation.

\section{References}

ABIOLA, S.S.; TEWE, O.O. Chemical evaluation of cocoa by-products. Tropical Agriculture, London, v.68, n.4, p.335-336, 1991.

ANZANELlO, R.; SOUZA, PAULO V.D. de; CASAMALI, B. Fungos micorrízicos arbusculares (FMA) em porta-enxertos micropropagados de videira. Bragantia, Campinas, v.70, n.2, p.409-415, 2011. 
BALOTA, E.L.; MACHINESKI, O.; STENZEL, N.M.C. Resposta da acerola à inoculação de fungos micorrízicos arbusculares em solo com diferentes níveis de fósforo. Bragantia, Campinas, v.70, n.1, p.166-175, 2011.

BARBOSA, Z.; SOARES, I.; CRISOSTOMO, L.A. Crescimento e absorção de nutrientes por mudas de gravioleira. Revista Brasileira de Fruticultura, Jaboticabal, v.25, n.3, p.519-522, 2003.

BERBERT, P.R. Estudo da pectina do mel e da casca do fruto do cacau. Revista Theobroma, Itabuna, v.49, n.2, p.51, 1972 .

BOLAN, N.S.; ROBSON, A.D.; BARROW, N.J. Increasing phosphorus supply can increase the infection of plant roots by vesicular-arbuscular mycorrhizal fungi. Soil Biology and Biochemistry, New York, v.16, n.4, p.419-420, 1984.

BURLEIGH, S.H.; BECHMANN, I.E. Plant nutrient transporter regulation in arbuscular mycorrhizas. Plant and Soil, The Hague, v. 244, p. 247-251, 2002.

BURLEIGH, S.H.; CAVAGNARO, T.; JAKOBSEN, I. Functional diversity of arbuscular mycorrhizas extends to the expression of plant genes involved in $\mathrm{P}$ nutrition. Journal of Experimental Botany, Oxford, v.53, p.15931601, 2002.

CARDOSO, E.J.B.N.; CARDOSO, I.M.; NOGUEIRA, M.A.; BARRETA, C.R.D.M.; DE PAULA, A.M. Micorrizas arbusculares na aquisição de nutrientes pelas plantas. In: SIQUEIRA, J.O.; DE SOUZA, F.A.; CARDOSO, E.J.B.N.; TSAI, S.M. (Ed.). Micorrizas: 30 anos de pesquisas no Brasil. Lavras: Editora UFLA, 2010. p.153-214.

CHU, E.Y.; MOLLER, M.R.F.; CARVALHO, J.G. Efeitos da inoculação micorrízica em mudas de gravioleira em solo fumigado e não fumigado. Pesquisa Agropecuária Brasileira, Brasília, DF, v.36, n.4, p.671-680, 2001.

COELHO, I.R.; CAVALCANTE, U.M.T.; CAMPOS, M.A.S.; DA SILVA, F.S.B. Uso de fungos micorrízicos arbusculares (FMA) na promoção do crescimento de mudas de pinheira (Annona squamosa L., Annonaceae). Acta Botanica Brasilica, São Paulo, v.26, n.4, p.933937, 2012.

COSTA, A.M.G.; COSTA, J.T.A.; CAVALCANTI JUNIOR, A.T.; CORREIA D.; MEDEIROS FILHO, S. Influência de diferentes combinações de substratos na formação de porta-enxertos de gravioleira (Annona muricata L.). Revista de Ciência Agronômica, Fortaleza, v.36, n.3, p.299-305, 2005.
DALANHOL, S.J.; NOGUEIRA, A.C.; GAIAD, S.; KRATZ, D. Efeito de fungos micorrízicos arbusculares e da adubação no crescimento de mudas de Eugenia uniflora L., produzidas em diferentes substratos. Revista Brasileira de Fruticultura, Jaboticabal, v.38, n.1, p.117128, 2016.

DOMÍNGUEZ, J.; GÓMEZ-BRANDÓN, M. Ciclos de vida de laslombrices de tierra aptas para el vermicompostaje. Acta Zoológica Mexicana, Xalapa, v.26, n.2, 309-320, 2010.

EL-SHAIKH, K.A.A.; MOHAMMED, M.S. Enhancing fresh and seed yield of okra and reducing chemical phosphorus fertilizer via using Va-mycorrhizaal inoculants. World Journal of Agricultural Sciences, Albany, v.5, p.810-818, 2009.

FARIAS, D.H.; PINTO, M.A.B.; CARRA, B.; SCHUCH, M.W.; SOUZA, P.V.D. Desenvolvimento de mudas de mirtileiro inoculadas com fungos micorrízicos arbusculares. Revista Brasileira de Fruticultura, Jaboticabal, v.36, n.3, p.655-663, 2014.

FIGUEIRA, A.; JANICK, J.; BEMILLER, J.N. New products from Theobroma cacao: seed pulp and pod gum. In: JANICK, J.; SIMON, J.E. (Ed.). New crops. New York: Wiley, 1993. p.475-478.

GENRE A, BONFANTE P. The making of symbiotic cells in arbuscular mycorrhizal roots. In: KOLTAI, H.; KAPULNIK. Y. (Ed.). Arbuscular mycorrhizas: physiology and function. $2^{\text {nd }}$ ed. Dordrecht: Heidelberg, 2010. p.57-71.

GERDEMANN, J.W.; NICOLSON, T.H. Spores of mycorrhizal Endogone species extracted from soil by wet sieving and decanting. Transactions of British Mycological Society, London, v.46, n.2, p.235-244, 1963.

JOHNSON, N.C.; GEHRING, C.; JANSA, J. Mycorrhizal mediation of soil: fertility, structure, and carbon storage. Amsterdam: Elsevier, 2016. 526p.

LEMOS, E.E.P. de. A produção de anonáceas no Brasil. Revista Brasileira de Fruticultura, Jaboticabal, v.36, n.1, p.77-85, 2014.

LIMA, K.B.; RITER NETTO, A.F.; MARTINS, M.A.; FREITAS, M.S.M.F. Crescimento, acúmulo de nutrientes e fenóis totais de mudas de cedro australiano (Toona ciliata) inoculadas com fungos micorrízicos. Ciência Florestal, Santa Maria, v.25, n.4, p.853-862, 2015. 
MCGONIGLE, T.P.; MILLER, M.H.; EVANS, D.G.; FAIRCHILD, G.L.; SWAN, J.A. A new method which gives an objective measure of colonization of roots by vesicular-arbuscular mycorrhizal fungi. New Phytologist, Oxford, v.115, n.3, p.495-501, 1990.

MOREIRA, F. M. S.; SIQUEIRA, J. O. Microbiologia e bioquímica do solo. 2.ed. Lavras: Editora UFLA, 2006. $729 \mathrm{p}$.

MORORÓ, R.C. Aproveitamento de derivados, subprodutos e resíduos do cacau. In: VALLE, R.R. (Ed.). Ciência, tecnologia e manejo do cacaueiro. Ilhéus: CEPLAC/CEPEC, 2012. p.597- 653.

NASCIMENTO, J.M.L.; SANTOS, M.R.B.; QUEIROZ, M.A.A.; YANO-MELO, A.M. Desenvolvimento vegetativo e associação micorrízica em plantas de mandioca adubadas com resíduo agroindustrial. Semina: Ciências Agrárias, Londrina, v.35, n.2, p.727-734, 2014.

NUNES, J.L.S.DA; SOUZA, P.V.D.DE; MARODIN, G.A.B.; FACHINELLO, J.C. Desenvolvimento de plântulas de pessegueiro 'Okinawa' inoculadas com micorrizas arbusculares isoladas de pomares de pessegueiros e de vinhedos. Revista Brasileira de Fruticultura, Jaboticabal, v.35, n.3, p.845-852, 2013.

OLIVEIRA, M.S.; CAMPOS, M.A.S.; SILVA, F.S.B. Arbuscular mycorrhizal fungi and vermicompost to maximize the production of foliar biomolecules in Passiflora alata Curtis seedlings. Journal of the Science of Food and Agriculture, New York, v.95, p.522-528, 2015.

PATERSON, E.; DAVIDSON J.; DANIELL T. J. Arbuscular mycorrhizal hyphae promote priming of native soil organic matter mineralisation. Plant and Soil, v. 408, n. 1-2, p. 243-254, 2016.

PHILLIPS, J.M.; HAYMAN, D.S. Improved procedures for clearing roots and staining parasitic and vesicular arbuscular mycorrhizal fungi for rapid assessment of infection. Transactions of British Mycological Society, London, v.55, n.1, p.158-161, 1970.

RAMOS A.C.; MARTINS, M.A. Fisiologia de micorrizas arbusculares. In: SIQUEIRA, J. O.; DE SOUZA, F. A.; CARDOSO, E. J. B. N.; TSAI, S. M. (Ed.). Micorrizas: 30 anos de pesquisa no Brasil. Lavras: UFLA, 2010. p.133-152.
RITER NETTO, A.F.; FREITAS, M.S.M.; MARTINS, M.A.; CARVALHO, A.J.C.; VITORAZI FILHO, J.A. Efeito de fungos micorrízicos arbusculares na bioprodução de fenóis totais e no crescimento de Passiflora alata Curtis. Revista Brasileira de Plantas Medicinais, Botucatu, v.16, n.1, p.1-9, 2014.

SAMARÃO, S. S.; RODRIGUES, L. A.; MARTINS, M. A. MANHÃES, T. N.; Da MOTA ALVIM, L. A. Desempenho de mudas de gravioleira inoculadas com fungos micorrízicos arbusculares em solo não-esterilizado, com diferentes doses de fósforo. Acta Scientiarum Agronomy, Maringá, v.33, n.1, p.81-88, 2011.

SANTANA, N.A.; FERREIRA, P.A.A.; SORIANI, H.H.; BRUNETTO, G.; NICOLOSO, F.T.; ANTONIOLLI, Z.I.; JACQUES, R.J.S. Interaction between arbuscular mycorrhizal fungi and vermicompost on copper phytoremediation in a sandy soil. Applied Soil Ecology, Amsterdam, v.96, p.172-182, 2015.

SHELDRAKE, M.; ROSENSTOCK, N. P.; REVILLINI, D.; OLSSON, P. A.; MANGAN, S.; SAYER, E. J.; WALLANDER, H.; TURNER, B. L.; TANNER, E.V. Arbuscular mycorrhizal fungal community composition is altered by long-term litter removal but not litter addition in a lowland tropical forest. New Phytologist, Oxford, v.214, n.1, p.455-467, 2017.

SILVA, E. P.; FERREIRA, P. A. A.; FURTINI-NETO, A. E.; SOARES, C. R. F. S. Micorrizas arbusculares e fosfato no desenvolvimento de mudas de cedro-australiano. Ciência Florestal, v. 27, n. 4, p. 1269-1281, 2017.

SILVA, D.K.A.; SILVA, F.S.B.; YANO-MELO, A.M.; MAIA, L.C. Uso de vermicomposto favorece o crescimento de mudas de gravioleira (Annona muricata L. 'Muricata') associada a fungos micorrizícos arbusculares. Acta Botanica Brasilica, São Paulo, v.22, n.3, p.863-869, 2008.

SILVA, E. B.; FARNEZI, M. M. M. Limitações nutricionais para o crescimento de mudas de graviola em casa de vegetação em latossolo vermelho distrófico do norte de Minas Gerais. Bioscience Journal, Uberlândia, v.25, n.6, p.52-58, 2011.

SILVA, F.C. Manual de análises químicas de solos, plantas e fertilizantes. Brasília, DF: EMBRAPA, 2009. $627 p$. 
SMITH, S. A.; READ D. Mycorrhizal symbiosis. $3^{\text {rd }}$ ed. San Diego: Academic Press. 2008. 800p.

SOARES, A.C.F.; SOUSA, C.S.; GARRIDO, M.S.; LIMA, F.S. Fungos micorrízicos arbusculares no crescimento e nutrição de mudas de jenipapeiro. Revista Ciência Agronômica, Fortaleza, v.43, n.1, p.47-54, 2012.

SODRÉ, G.A.; VENTURINI, M.T.; RIBEIRO, D.O.; MARROCOS, P.C.L. Extrato da casca do fruto do cacaueiro como fertilizante potássico no crescimento de mudas de cacaueiro. Revista Brasileira de Fruticultura, Jaboticabal, v.34, n.3, p.881-887, 2012.
SOUSA, D.M.G.; MIRANDA, L.N.; OLIVEIRA, S.A. Acidez do solo e sua correção. In: NOVAIS, R.F.; ALVAREZ V., V.H.; BARROS, N.F.; FONTES, R.L.F.; CANTARUTTI, R.B.; NEVES, J.C.L. (Ed.). Fertilidade do solo. Viçosa: Sociedade Brasileira de Ciências do Solo, 2007 p.205-274.

STATSOFT. Statistica: (Data Analysis Software System). Version 12.0. Cary, 2013. Disponível em: $\leq$ www.statsoft. $\underline{\mathrm{com}>\text {. }}$

TEAM, R. Core. R: a language and environment for statistical computing. Vienna: R Foundation for Statistical Computing; 2017. 